の如く常溫では正偏析をなし250遑では逆偏析が一番著 しく高溫になると差が少くなる.
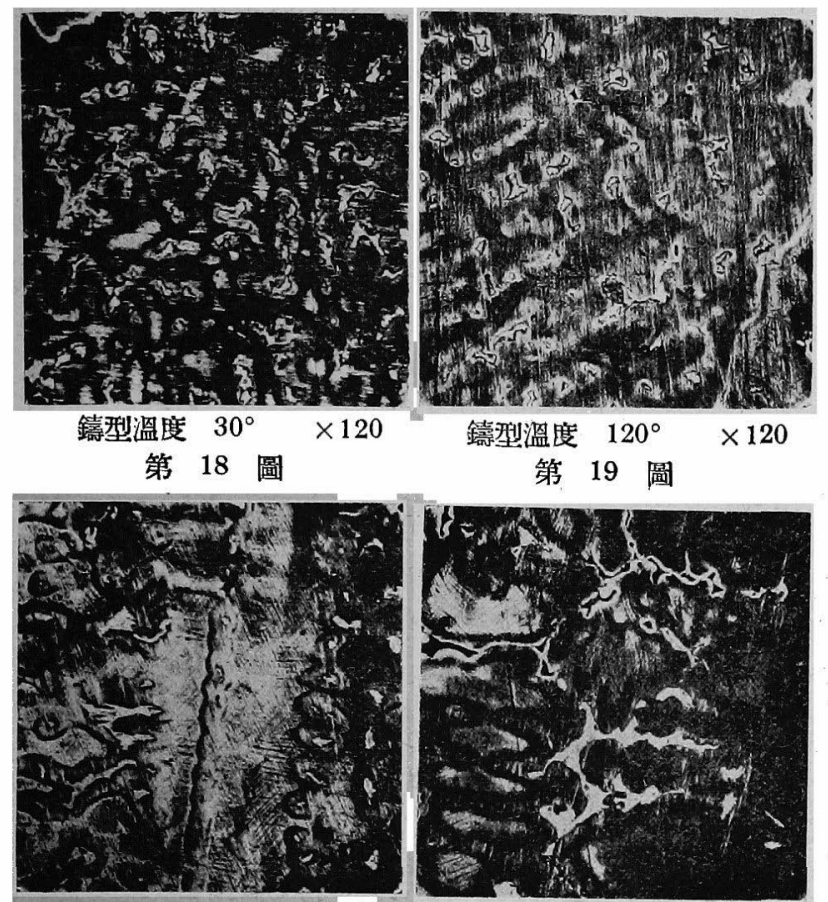

鑄型溫度 $200^{\circ}$ 第 20 圖

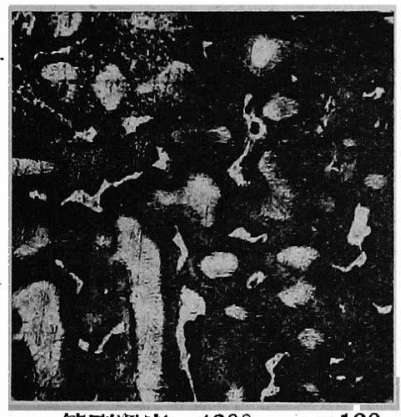

鑄型溫度 $430^{\circ} \times 120$ 第 22 圖

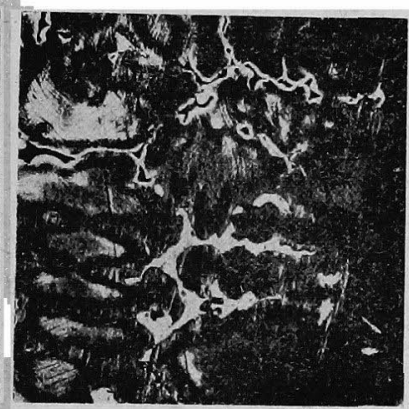

鋀型溫度 $270^{\circ} \times 120$ 第 21 圖

(7) 水壓試驗

水焎試驗は第 1 圖の試 料を $\mathrm{AB}$ 線で切㫁し中心 より 12.5 粍の所氏 $\frac{1}{3}^{\prime \prime} \varphi$ の孔を 45 楀の長さに第 孔し試驗を行つた其の結 果は第 13 圖の如く溫度 に依る差は餘り認められ

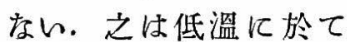
$450 \mathrm{~kg} / \mathrm{cm}^{2}$ 以上の耐水
壓度を得られた時に比較して高溫度の钀型では耐水厭度 は餘り期待出來ない樣な結果となつた。

水昷漏洩部の組織は第 18 圖乃至第 22 圖の吙くであ り多數の收縮骂が認められる。な樹狀組織は抗張試驗. 片と同樣に溫度と共に大きくなつてるる。

\section{IV. 結論}

中間教告であるので今迄の結果から続論を下す事は困 難であるが，上述の結果を綜合すると次の如き事が云へ ๖.

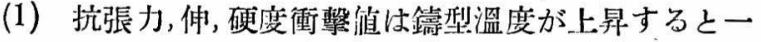
時減少するが再び上罚し $300 〜 400^{\circ}$ で最大となり其以 上では再び減少してるる. 然し水壓試驗片の試料から探 取した抗張試噞非は之と多少喰ひ違ひを生じをが之は肉 厚が抗張試驗片の試料と異るため偏析, 試料局部の冷却 速度の差が大なる影響を與へてるるものと想像される。

(2) 粒子の大さは大體抗張力之同じ傾向にある・然し 樹狀組織は粒子の大さには比例してるなん，之は合金の 結晶核發生速度と結晶發達速度に關係してるる事である が,判然としない。

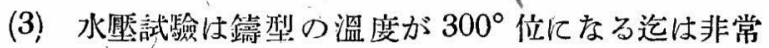
に變化が多く不安定であるが $300^{\circ}$ 以上では比較的安定 して來る. 然し此程度では渜水壓度は䥂型の溫度に餘り 期得出來ない，寧万耐水賍度は $0^{\circ}$ 以下の低溫度の時の 方が期待出來る梯に想像される.

以上の如く大體常溫乃至 $200^{\circ}$ の間が何れの場合も惡 い結果を示し $300^{\circ}$ 以上で想像し得なかつた結果が得ら れた事は現在の煖造法に對し一つの指示を與へるものと 信ずる．然し實際の製品に對しては形も複雜となり他の 要素も入つて來るから台研究の餘地を存するもの之考へ られる。

\title{
鐵鑄物の缺陷並にその除去法
}

\section{1. 緒}

\section{言}

今日私共が經驗してをる鐵鍧物の缺陷を數へ上げると 隨分数多くあつて恐らく十數種をてすものであららと思 はれますとれ等の原因を調べますと各々に又數程の原 因があり，その內には喚め判然せ婸合も政くなく，從つ

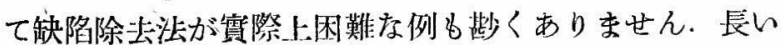

\section{齋 藤 彌 本*}

間の經驗をるつてをる找術者の內で時々自分の關係して をる仕事に對して自信をぐらつがせられる例がもしあ りとすれば，それは鑄物關係の技術者に最も例が多いの ではないかと云つてb過言でないと思ひます，俗に鑄物 は水物であると云ふ樣な事が今日でも一部で云はれてを

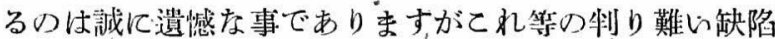
發生の原因子，缺陷の種類，狀態老任紐に分析檢討し，理 論的考察並に實驗を怠らないならばその原因も判明し結 


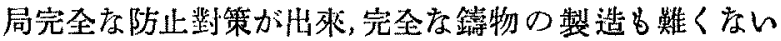
と思ひます。

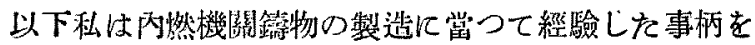

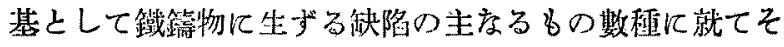

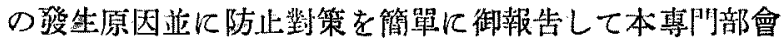
の御參㹲儿供し度いと䍐凹中す。

\section{II. 鐵鑄物に發生する缺陷の種類还に防止對策}

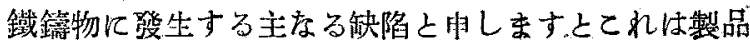

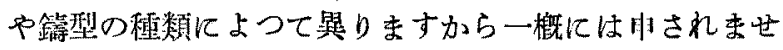

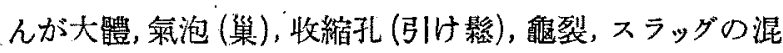
入，湯塄及び硬すぎその他寸法不良等がその主なるるの と思はれます。これ等の内氣泡に就きしては先程天利 さんから詳しいお話がありましたので省略致し、それ以 外の缺陷江就て㬰上げ度いと思ひ委す。

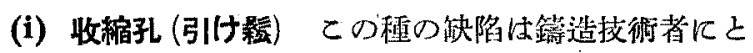
つて最も嘼老惱ます問題の一つでありまして根本は設計

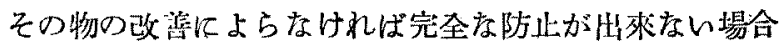
が需くあります。

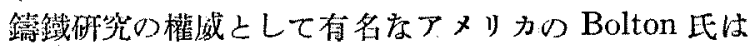

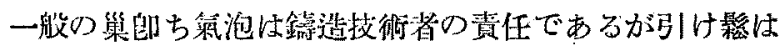

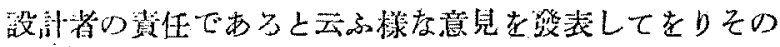
他にも同じ意見の人が尠くありません。

さて引け愁には大體二つの程類があります。一つは肉

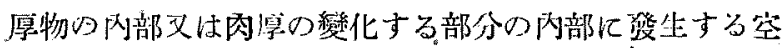
虚な㑑所，所謂一般に“引け”之云はれるものがそれで あり猲逸ではこ就老特に“Innen Lunker”と云つてを り又英，米では漠然と Shrinkage Cavity と云つてをる のがそれであります。この空焉な個所をよく調べると金

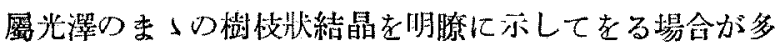
く時に，中子文は湯から來た瓦斯の影響をらけて溥青色

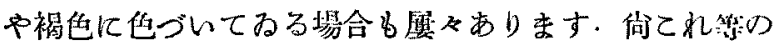
缺陷は网厚部を割つて調べるとか，內部を通して孔をあ けると加の加工をしてみ度いと氣付かね場合多く，义水

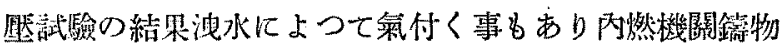

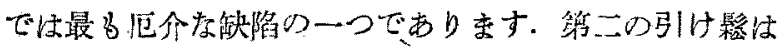
主として肉曆部の上型面とか, 赺出部の根元とか反生じ た山みがそれで所謂外引けとも云ふ可をものであつて䚑 兔ではこれを“Aussen Lunker”之云つて內引りと區别 してをり，英，米では吡に Sinks と云つてをるものがそれ であります。これ繁い外引けがひどく起つた場合には割

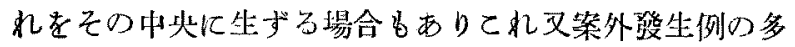

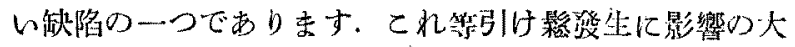
きな要因としては炏の凹種が考へられます。

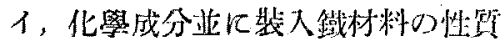

口，銡込溫度並に時間
八, 設計。

二，湯口;掦り等の切り方

由す迄もなく理論上から云へば引け箖發生の主なる原 因は先程本多先生の御話にもありました通り凝固收縮師 ち邀固し始めてから凝固完了迄の間に於ける容嫧の變化 が最も大さな要因であつて斯る凝固收縮の大なる金風は 引け筙を生じ易く，凝固收縮のでく少ない入は凝固の際

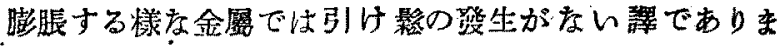
す.これを鋀鐵の場合で申しますと炭素の含有されてを る量之狀態例へば品鉛炭素の形か或柱化合炭素の形で入 つてをるか，その量の多い少ないによつて邀固收縮の上 几影響があり，例入代炎素が少い程凝固收縮は大をくこ れに反して装素が多く然も哭鉛炭素の形で析出してをる

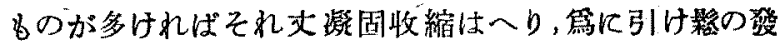
生が出來難い事になります，先程本多先生がま話になら れました队にも炭秦量と凝国收縮量の變化の實例が出て をりますし又Ash, E.J\&Seager 兩氏の實驗結果の發表 它りま方。後者の例に依ると㠜国收縮量は過共晶成分

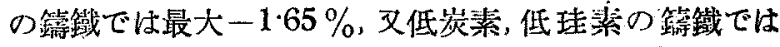
$5.85 \%$ の值を示した事老郝告してをります。(1)何れにし

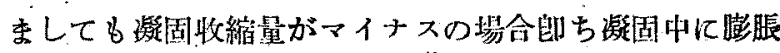

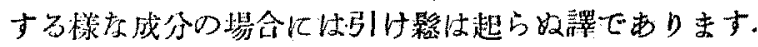

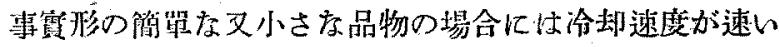

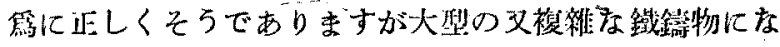
りますと今度は片將品敍の析出に依る湯の補給力の妨害 作用等が考へられ必ずしも凝国收縮の少ない管の成分丈

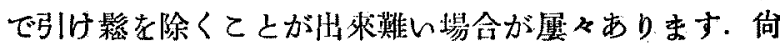

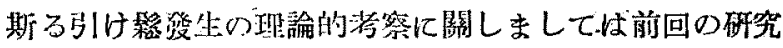
部會に然て詳絸な松浦氏の御發婊(2)がありますので妾で は省狢致し，只䤲物製造の筫際に於て考人られる引け矮

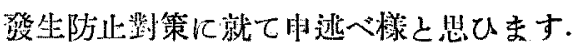

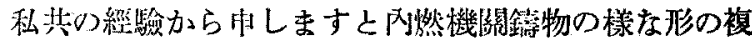

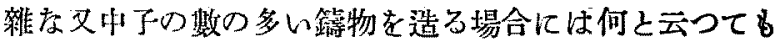
知張りその化學成分が肉厚部の引け箖發生に最子大きい 影贸をもつてをる事を痛感致します。

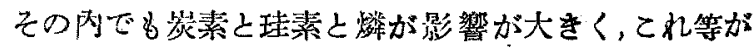
不邀管な場合には殆ど $100 \%$ と云つても良い位に引け

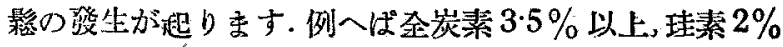
以上の篟鐵で闪厚變化のある複雜な形の簿物を造つたと するとその肉厚 50 粍以上の部分はその內部にどてか均

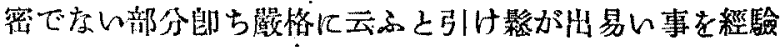
します，比冷金や，湯口，掦りの切り方で多少防止する 事が州爽るとしてもその內部を忖上げて水涯試驗をする と減水する事がよくあります，更に同時に燐が多い場合

(1) Transactions, Am. Foundrymen's Ass, 40 (1932).

(2) 本赭, 昭和 16. 1. 
垖ち $0.5 \%$ 以上の場合には向一層引け影の發生の機會が 多くなります・之に反して上記の成分でも炭素を $3 \%$ 附

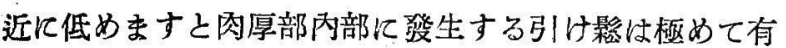
効に防止する事が出來ます ての場合特に注意すべき事 生、炭素が下つた爲に凝固收縮が大きくなり今度は肉厚 部の外表面に外引けが起り易くなつて，湯口や，掦り抑湯 等のつけ方に注意を拂はない之案外この種缺陷による仕 損品が多くなつて参ります 殊て生型唋物の場合儿佮一

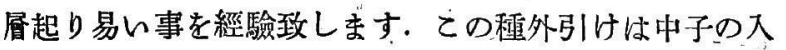
つれ內部の突出部等に生じを場合は發見し難く，又時に 氣泡に依る缺陷の吹かれ之見誤る事がありその對策に苦

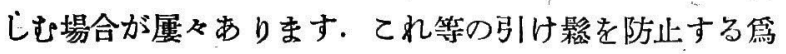
には第一に引け僰の生じ易い個所に相當太い掦りををて， それから湯を補給してやる事が最も有效であり捷徑であ ります。更に又湯口を成る丈肉薄部にきり，徐々に湯を

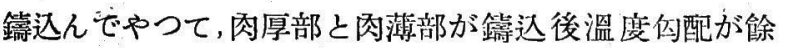
り大きくなら收樣注意する事が肝要な事であります。 後に出てくる例の㥞に或場合には斯る湯口の切り方丈で

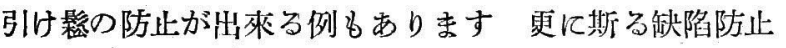
の理想的な例を舉げれば䥂込まれを品物が湯口上り一番 遠い部分から段そ湯口の方に向つて凝固して來て最後に

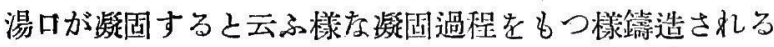
事であつて出來る丈その主旨に则つた湯口の切り方等そ の他䌇型製作の上に注意すべきであると思ひます。一體 一うの鑄型內の品物を湯が滿をして場合その各部に於け

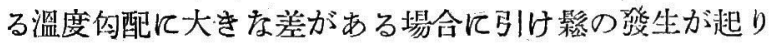
易くなるのは當然であつて,高溫の部分と低溫の部分では 湯詰りも違ひますし，又低溫の部分では初晶が出始めて 流動性が恐くなり，その部分から附近の肉厚部に對する

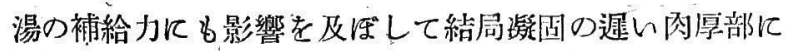

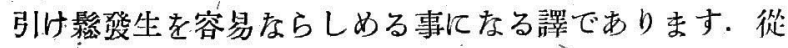

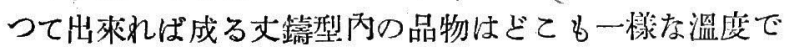
凝固する事が理想的な譯でありますが䁈際上は至難であ

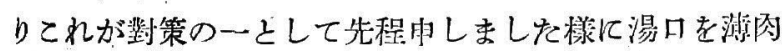
部に切り，そこをあとまで通ふ湯で鋀型を溫めてやり，結 局肉薄の所も冷却は肉厚部のそれと同じ程度に近づけ樣 とするのがその目的であります 斯る對策で佮不十分と すればやはり冏厚部に太い掦りをつけて其處から最後に 固まる肉厚部の队部に湯の補給をしてやる事が必要とな る譯であります，理論的に云へば丁度湯を滿たし終つた 時にどても凝固を完了する樣な湯の入れ方学工夫する事， 換言すれば湯の满たし終つた時期之凝阁完了の時期とが 出來る丈相接近してをる嵄な湯の入れ方になる梯蹻型の 止め方之湯口ふ放り方を工夫すれば引け鬆は出ない事に なりますとのRoncery 氏の提策の“pencil'gate”と云ふ 湯口の切り方はての點を主要な目的として考策されたも
のでありまして,てれは鉛筆の軸位の太さの湯口を澤山 切つてそれから落し込みで相當な速さで然も一樣に签込 んでやつて,最初鋀迅まれを部分から次々と順々儿凝固 が終る様, 從つて一番最徭に固まる處が湯口の附近と云 ふ事になり引け彭發生が最も少な山鋀达法であると云は れてをるものであります

私步子斯る湯口の切り方應用して好結果納めた例 老相澢持つてをります，例へばシリンダーライナーとか 勢車とかの樣な形の简單な製品に特儿都合がょく第 1,2 圖はその實例を示したものであります。

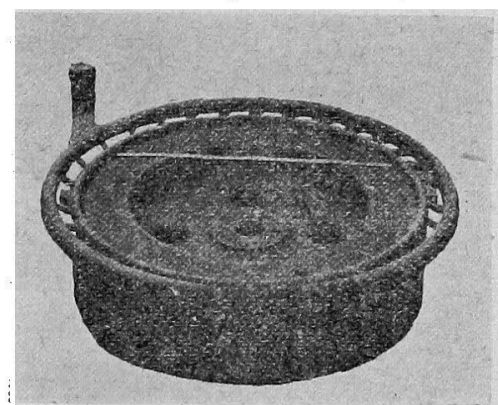

第 1 圖フライホイール
從來勢車は第 3

圖つ樣に側面に相 䔰太ん湯口を切り その反對側の上部 に大をな掦りをつ けて其處を長時間 熔融狀態に保つ丞” に所謂“ズンべ”。 と云つて, 鐵棒を

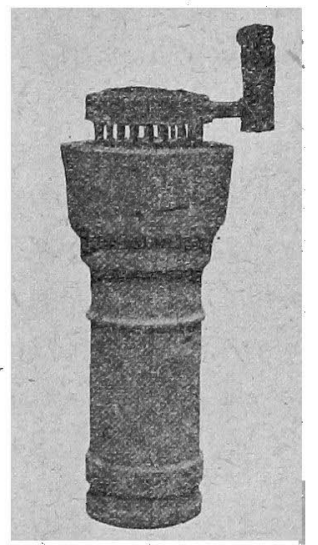

第 2 圖 シリンダーライナー

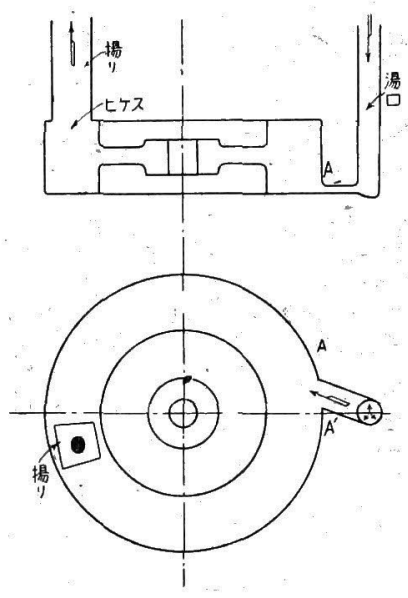

第 3 圖 フライホイール
恙しこみ上下につを初晶の成生起迠らせ乍ら湯老補給す ると云ふ厄介なやり方をやつてねたのであります。その 宜しを学得なかつを場合には却つて掦りの下部に引け鬆 が䇅つ它り, 又湯口の根元注入口附近 $\mathrm{A}, \mathrm{A}^{\prime}$ 部の砂が之 ばされたりして不良品の出る危險が相當あつたのであり ますが符 1 圖の樣な湯口の切り方に改めてからは引け檠 發生の缺陷が皆傿となりました，向ての湯口の切り方が 第 3 圖のそれに比へて砂落しの手數更に又機械加工の手 数在遥加に低減した事は中す迄もありません，又シリン ダーライナーも第 2 圖の如き湯口の切り方が第4圖の如き それに比べて經加工後 A なる街帶部に發生する引け鬆

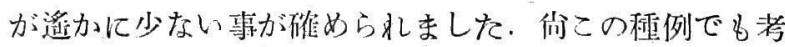
へられます樣に湯口の切り方に落し込み式 (top casting) 
と押上式 (bottom casting) と二種ある譯でありますが てれ等の何れが引け鬆湓生防止の上から見て良法かと云 ふ事になりますと,私は理論上からは落し込み式湯口が 優れてをると思ひますそ

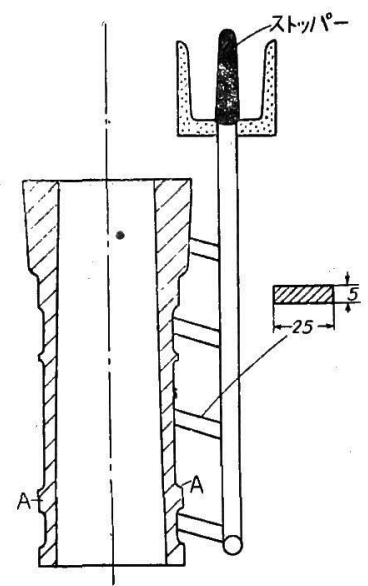

第 4 岡 シリンダーライナー れは先にも曺述べました樣 に落し込み湯口の場合には 湯口に近い程凝固完了がお くれ; 所謂鋞达完了時期之 凝固完了時期之が比校的接 近させ易く湯の補給力が有 效に制いてをるのでありま すが，押上式湯口の場合に は最初鑄达まれた湯が冷 め午ら次第に上方に上つて 來るため策外速く㠜固を始 め, 鑄迈完了時期之凝固完 了時期とが可成り離れて參

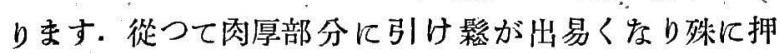
湯, 掦りの効果が減殺され勝となります。乙饥等を防止

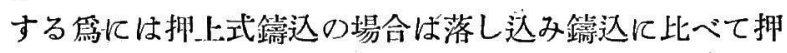
湯，掦りを大きく相栄數つげるとか, 豫備湯口を切ると か, 又場合に依つては押湯の下部又湯が上つて來た時に 注入を止め, 抑湯には别に高溫の湯を注入してやるとか， 押湯, 掦りの鈈砂を特に考慮して其處の冷却が一層綬慢 となつて少しでも長く熔融归態に保たれる栐豫め工夫し てやる必要があると思ひます。

何れにしましても根本的方案としては模型その物加ら

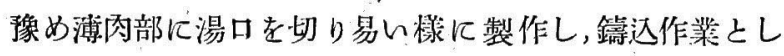

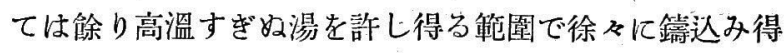
る樣工夫する事が有效な引け惖防止策と思はれます。乙

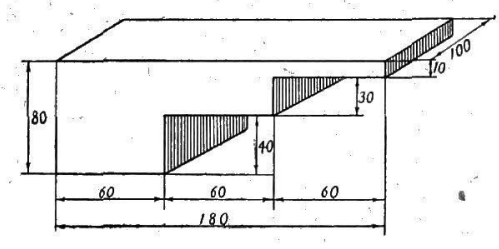

第 5 圖引け彭試詥片

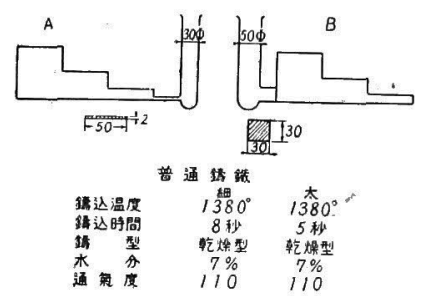

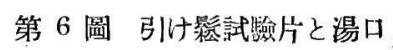

れに反して肉厚部 に大きな湯口を切

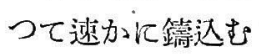
場合には殆ど碓實 と云つてもよい位 に肉厚部に引け鬆 が發生致します。

第 5 圖は私共の處 で實驗した引け鬆 試驗片の寸法を示 すものであります がこれに第 6 圖 A，B に示寸樣に 湯口の切り方變 更して同じ成分の普通鑄鐡(T.C $3.56 \%$, Si 1.75\%, 1·14

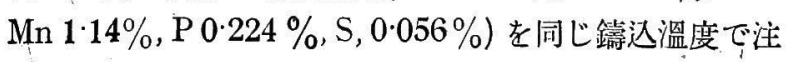

レだ結果が第 7,8 圖であります. 師ちこれは試驗片の 斷面組織を示したものでありますが,第 7 圖の如く溥肉 部に細く切ゔ湯口の場合は肉厚部の中央部も比較的一 樣な密を組織を有してをるに反して,第 8 圖の樣に肉厚 部に太ん湯口を切つて速かに鑄込んだもすでは肉厚部の 中央近くに明が相當大きな引け影が發生してをり然も 全體として粗粒であることが認められます。事實形の簡 單な製品は細湯口のきり方丈に依つて引け鬆發生を防

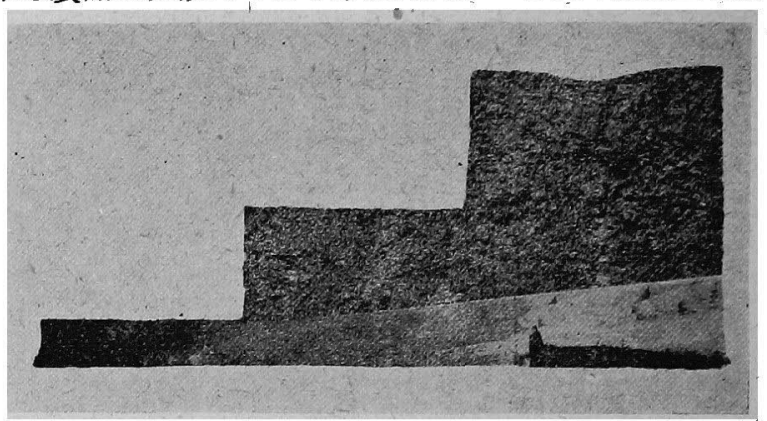

第 7 圖 細 湯 口 (第 6 圆 A)

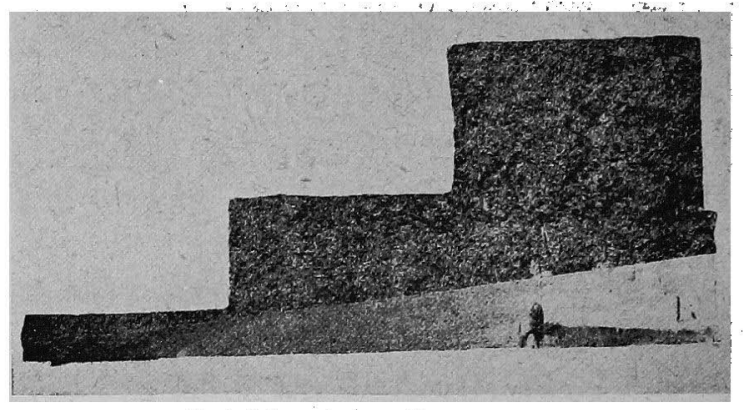

第 8 圖太湯 太口 (鹈 6 圈B)

止しを例が幾らもあります，倘引け彭發生防止策の一つ に冷金の使用之云ふ方法があります併してれは時に

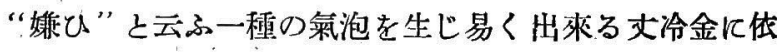
らずに止むを得ない場合にのみ最後に用ひると云ぶが 良く，原則として前述の湯口及び掦りのつけ方をエ夫し てそ礼几依る事が效果的と思ひます 向又裝入鐵材の性

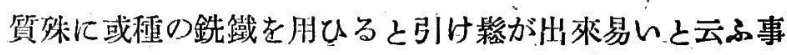
はよく云はれてをる處でありますがでの點て就ては制然 とした研究結果をもつてをりませんので確言は出來ませ ん. 只成分の調整け同じ材料を用ひるがをめに化學成分 が不適當となりり引け鬆發生の耭會の多い事は認められま す何れにしましても形の簢單なものでは割合に容易に 理論上から有効な對策がちて易く且つ結果も良好な例が 多んのでありますが、複雜を形をもつてをるもの，例人ば シリンダーブロック,シリンダーカバー等の如く中子の數 も相當多いものになります之湯の凝固過程や補給の方向 がなかなか理論的にのみ見透しをつける事が困難であつ て合理的湯口，掦りのつけ方が判然せずに迷ぶ場合が尠 くありません. 又或る場合に引け鬆發生防止には有効な 
對策でも，今度は湯堺が起り易くなつをり，龜裂筑生が容

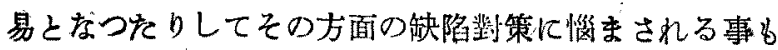
あり得る譯であります 從つて試驗沜の場合丈で引け影 防止龂策ををて」も嘪際製品の場合には不十分であつ て，㣀の對策は實際㹕品を陚作してれが各部家切斷して

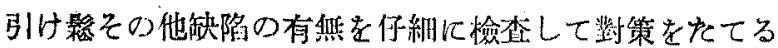

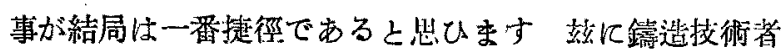

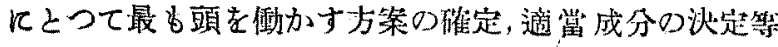
の問題が附隨して起る事几なる譯でありますが完全な引

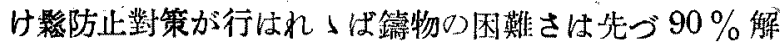
決し得たと云つてb過言でないと信心゙す。

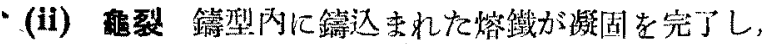
次で常温迄泠却する閒儿缊度の降下之共に收縮が起る譯

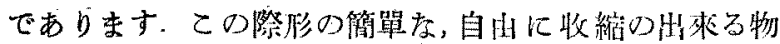

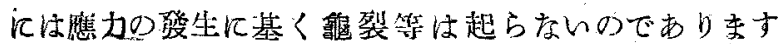
が, 嘪際の整品に在る之肉厚不同の㑑所，中子のすはり方

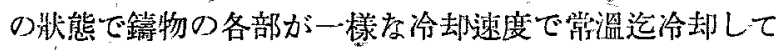
くる事は殆ど不可能な譯であります。それ政所によつて

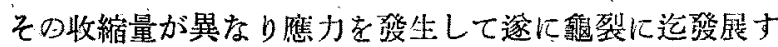

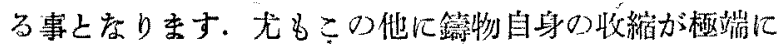
妨げられる場合例へば，中子が堅すきる場合之が签型の 砂か堅過ざて牧縮その物圭妨げる場合にも鬼裂は起りま すがこれは鏟型製作の技術の上で防止する事とし私は熱

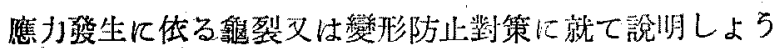
と思ひます。借これ等の缺陷發生に及结す要因考舉げま すと (1) 冷却速度の不同 (2) 化學成分の不適當 (3) 應力蔡生個所の强度不十分，等の三つの埸合が洘へられ ます，この內で女（1）の冷却速度の不同が最も大をな影 響をもつてをる要因である事は中す迄もありません，郎 ち部分により冷却速度の不同の度合が著しければそれ丈 收縮量を異にした結果發生する熟應力が大きくなりま 寸處でこの泠却速废は品物り肉厚に大體比例すると考 へても宜しくありますから綃局肉厚の不同のある程應力 發生傾向は多くなり，酠裂や變形心起り易くなる事は笛

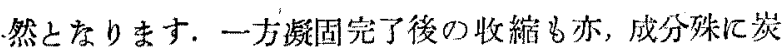

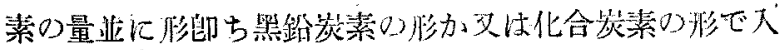

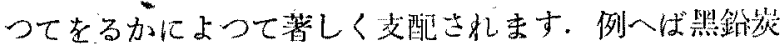

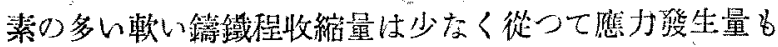
少をい譯であります

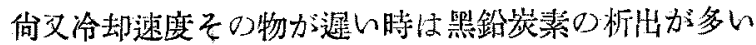
譯ですりますからどの方面から洘へても冷却速度の非い 事は結局應力發生量を少なくして䮦裂，變形防止に忙大

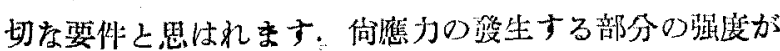

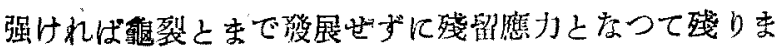
すから後で除去する事名出來ますので酠裂發生の危險の ある部分に“リブ”をつけをり“王ぶち”をつけたりす

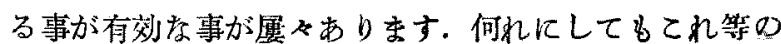
触降除去法上しては冷却速度の急激な不同矯正する事 が肝要であり，それが雼の賽際的方法としては

(1) 湯口ひ切口方を工头し出來れば細い湯口を數多く

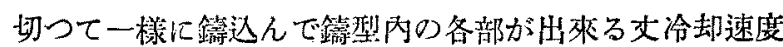

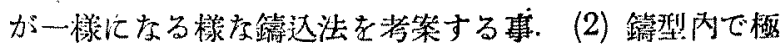
端に早く冷却する核な溥肉上をる部分を豫熱してをく事。

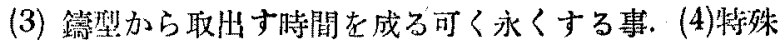

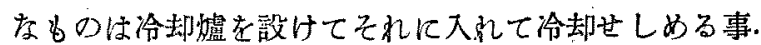

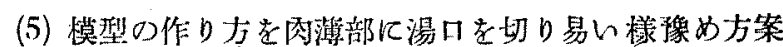
する事. (6) 設計その物る出來る文均等な肉取りにをる 㥞工夫する事，份叉中子は心金その他の込め方をエ夫し て出來る丈地金の收縮几對して抵挖少な樣製作する 專等が考へられ李す。一方地金の成分必規格の訢し得る

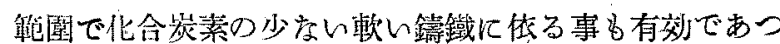
て，例人ば私基の處で製造してをる或型のヂーゼル機閔 のシリンダーコラムではFe 3.2, Si 1.5\%程度の成分の地

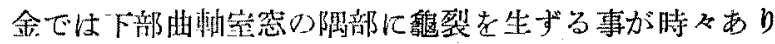

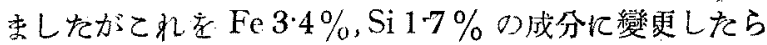

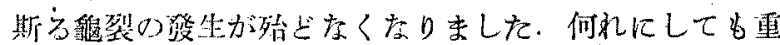

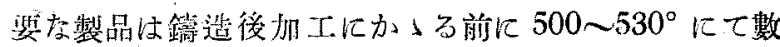

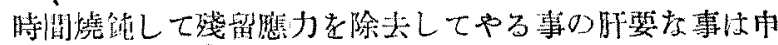
す迄りありまん。

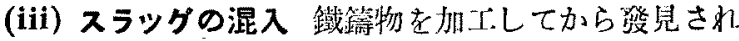

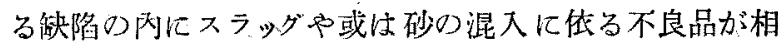
當多い事は私共の日常經驗してをる゙處であり主す，尤も

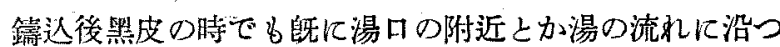
た品物の鑄肌に一見して制るスラッグの泿入した跡を見 ることも屡かありますが多くはシリンダーやシリンダー 入子の内徑值に加工娞スラッグが残つて不良品となる場 合が多いもであります てれ等の原因を考へる己（1) は湯の中にスラッグの混在が多くてれを鎮靜不十分で且

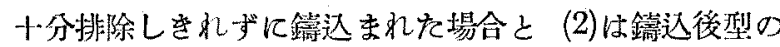
中でスラッグが發生しそれが品物の內部で凝固して含ま

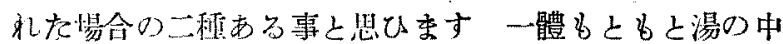

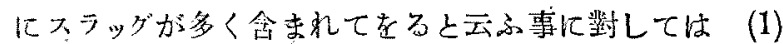

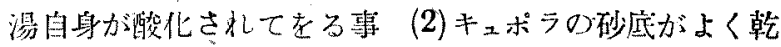
燥さ机げて㬎つてをつた場合 (3) キュポラの湯山口の 桶や取鍋のライニングの耐火度の低的場合 (4) 山銑さ れな晹が低溫のため含有してをるスラッグを上方に浮

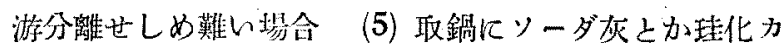
ルシウムとかり特殊深加物を用ひを鹞成生スラッがが多 量となりその除去が十分に行はれなかつを場合等が主を る原因となりますからその防止對策は自ら講じ得る譯で

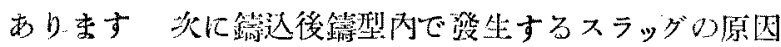

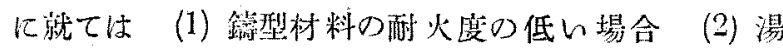


口の切り方が不適當で局部的過熱を生じ簅肌砂が犯され た場合、等が洘へられます，何れにしましてる、ラッグ混 入の除去法としてはキュポラ.ライニングに耐火度の强い 煉瓦老用ひる事，又装入不灰石老計算より過多に月ひぬ 事等が先汒閒題であり，實際閒題ししては取鍋の湯面の スキミングに十分の注意を排し、簿込法としては出隶る 丈ストッパー式に依り且ストレーナー湯口を教るる事等 が有效度龂策と思はれます，绱これ等の湯口の切り方に 關しましては Pat Dywer 氏が 1931 年の Foundry 誌上 に1ケ年に亘つて詳しい貝例を揭げて說明してをります

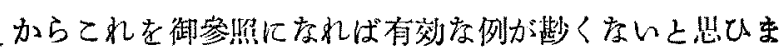
†.

俻又獨逸では必宓湯口と“七キ”との山間にスラッグ

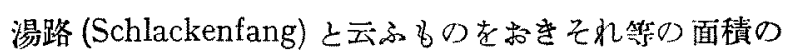

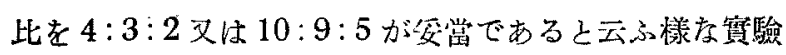
結果を弡表してをります. ${ }^{(3)}$ その他湯の流れを理諭的に

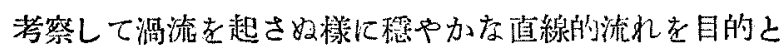
してスラッグ混大淡生を防ぐための鐴达速度や湯口の太

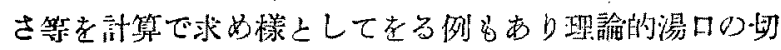

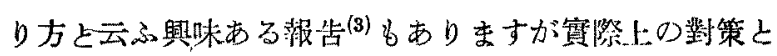
しては京かなか至難である栐であります

(iv) 湯堺 乙の租の缺陷当船物籍物を製造する際に

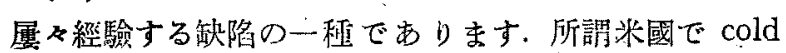
shut と云はれるもの又熘逸で Kaltschweissen と呼隹 れてをるものがそれでありますてれは一つの簅㞦面に 丽方から漰たして來た湯が相接して融合せずにその舅凝

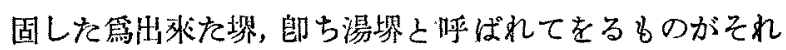

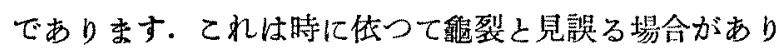
ますがてれをよく調べて見るとその內面はスベスべして

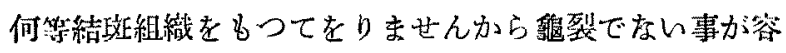

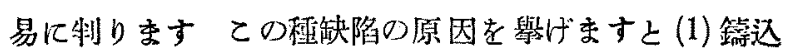
溫度が低すざた事，(低溫で出て來た湯の場合も同棏) (2) 湯足のない湯 (3)湯口の切り方の不適當な場合 (4) 䈥

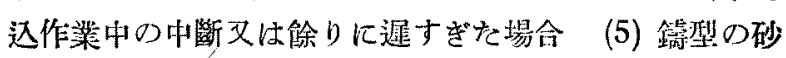
の达め方が壁すぎた場合箱であります，從つててれ等の

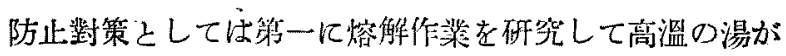

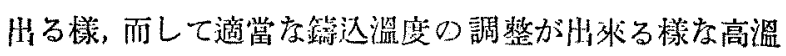
の湯が得られる事が先汹問題であります 又湯足のない 湯は兔角低炭素，低䗇の成分に起るものでありますから，

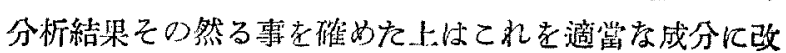
めてやる事も必婴であります。份又キュポラ熔解で装入

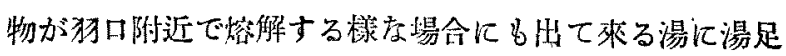

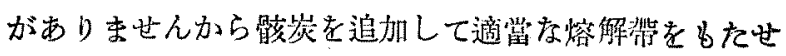
る樣注意して操栄する必要があります 又湯口の切り方

(3) Úber das Anschneiden von Gussstücken. Die Giesserei, (1938), Heft 11. H. Lips \& A. Nipper.
が不道崰な篇に生じたと思はれる湯堺に對しては斯る缺 陷の起りそらな侗所により早く湯が通ふ漛察際に當つて 湯口の位置，大さをかへる事が必要となります 倘又鋳 型砂の通氣性を改良して良いものを用しる事も一つの對 策であります，斯くしてての䅜缺陷の除去は比較的容易 に行ふ事が出來ます。

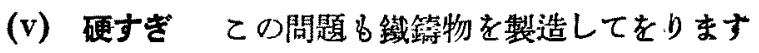
場合に割合に經噞する事の多い缺陷の一つであります。 これには製品全體が堅くて加工が困難な場合と，或一局 部に堅い所があつてバイトがか」らぬと云つた様な所謂 hard spot (硬點) の場合との二つがあります。てれ筫の 原因は勿論材筫に依る事が多いのでありまして(1)は成 分が低炭素,低珪素すぎる場合又はクローム、マンガン等 の菼化物の安定度を粡す元素がその品物の肉厚に對して 多すぎた場合に起ります（2）には低溫の湯で鏟込んた 場合、殊にそれがニッケルとかクローム等の如き合金元素

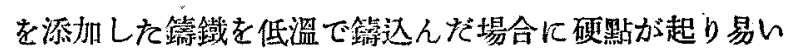

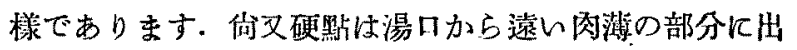

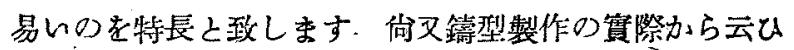

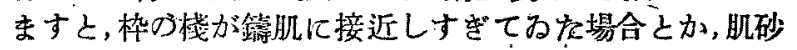
の中に玉金よかコークス粉の大うてねた場合にも起りま すし, 又冷金の用ひ方の不適當索場之か,中子の心金が 肌砂を通して外表面に現はれてをる處に湯が篟込まれた

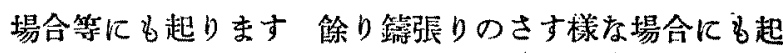
りますがてれ残は䇺型製作の上で注意して對策を講ずる より他はなんと䍐います何面に全般的注意としてはて 双等の場合にも溥肉部に湯口を切る事の出來る樣嶑め模 型をてめつけるから注意する事が肝要と思儿ます，何れ にしましても斯る堅すぎと云ふ缺陷は案外不愉快なるの でありまして，殊に多量生屖用の鑄物を製造してをりま 寸場合には製作工程の上で流れ作業に大きな障害を來す ๖のでありますから十分な考虑と對策を講ずべき䦕題と 思ひ素す。

\section{III. 結面}

以上で鐵鎬物に經驗され方缺陷の中ででく代表的のも の數程に就てでく䔈際的方面の考察並几對策を中上げま した．これ以外にも向十數種以上の缺陷であると思ひま すがてれ等は大體に於て綿密な注意で防止し得るものが 多いのであります。次に斯る諸缺陷㡎生の割合を若へま すとこれ等は製造する製品や鏟型の程類で違ひますから 一定的傾向は中_上げ難とと思ひます。一例としてとく 最近の1ヶ月間私共のところで經驗した乾燥型を用ひた

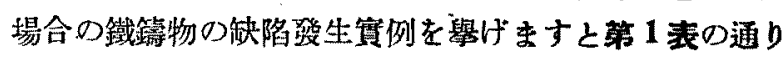
であります。てれ等製品には1 1 數䏕位の小さな物から 10 酶位の大物迄を含む內燃機關部品でありまして工數 b數時間位のものから數百時間に及ぶものもあり材質も 


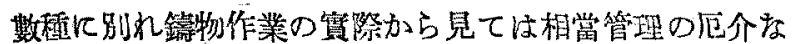
工場の例でないかと思ひます，不良品內譯を仔細に檢討 すると作業の頡際, 工員の素翼又は製品の難易，更に又檢

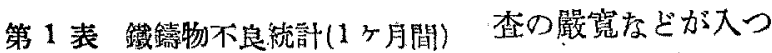

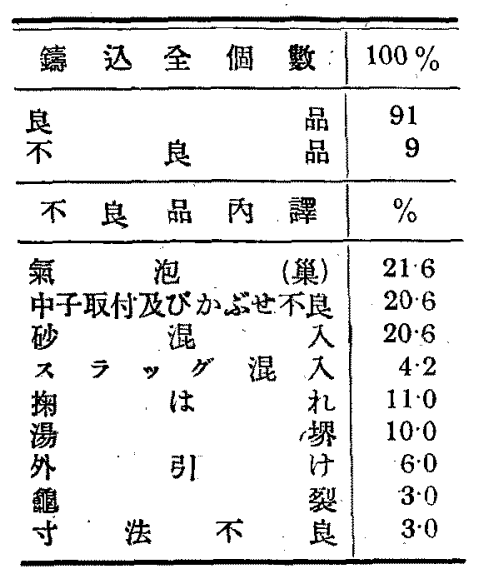
て來て興味る考察 が下せる日でありま すがこれ等は玆では

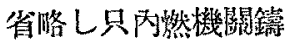
物は中子の數多く之 れ水衣室等の椱雜 㳊8のが多い雲に中 于取付の不良や，"カ ブセ”の不良，及び それに閵聯して砂の 混入したまっで歵达 まれる。，或は㧶 はれ等案外製型技街化關する不良の多い事が注目すべき

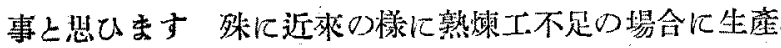
增加を計らねばなら始現狀ではこの程缺陷の增加は必然 的の事之思はれ恐らく各方面に於ける仕損品の增加とそ の步調を一にしてをる好のであららと衫じます。

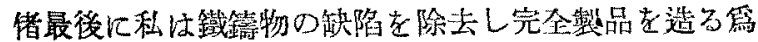
の睿の根本方针如何と云へば头の數項索擧げ度いと思ひ ます。

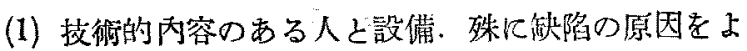
く判定しその㖶策在建て得名人の養成充筫.

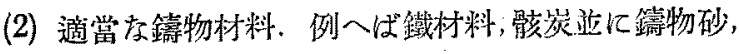
殊に高溫にして所要の組成を有する熔鐵を得るに 適棠しを鐵材料と骹炭等。

\section{鋼 躊物の龜裂に就て}

\section{はしがき}

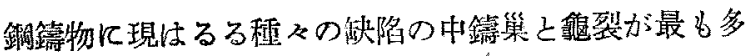

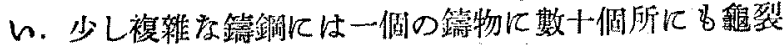

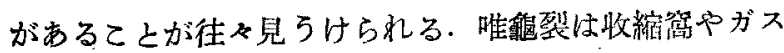
孔等の如く肉の中心部に存在することは尠く，多くは外 皮より發㒓してるる故，電氣熔接などで補修の上使用し て居る狀態であるが，重要な部分に使肚さるる品物には， 揢接が許され姟合もあり，又檢查不十分のため龜裂の あるまま使用し，思はざる奖害を惹起した例も赻くない。

\footnotetext{
* 海禹技街研究所
}

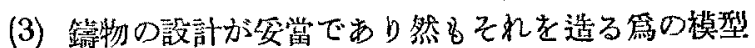
が䇺达に際し適當存湯口を切り良い橙且つ變形等 のない様造られてをる事。

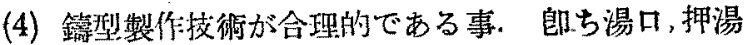
のつけ方然が最も合互的に行はれ然も通氣性, 强 度密を十分上く考虑した型が造られてある事。

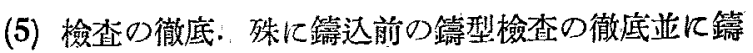
込後の製品檢售老綿密に行ひつねに缺陷對策を总 らぬとと

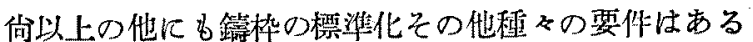

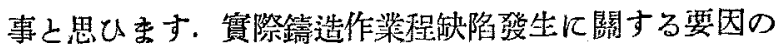
多くをもつてをる作業は他には整い事と思します。この

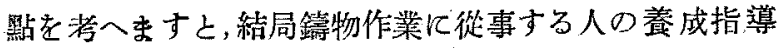
が何よりも大事な問題であると結論されるのであります

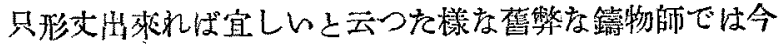
日の機械鋀物の完全なものは到底出來難んのでありまし て，材翼の事当，熔解の點子，又製梨技眞の理論に就ても

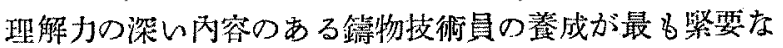
缺陷除去根本策であると云つても過言ではないと思ひま

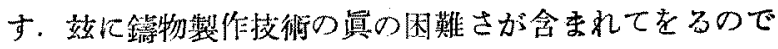
はないか、然もこれを實現しなくては到底真の完全な鋞

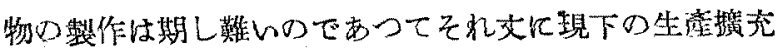
に大きな役割をもつてをる篻物關係技術者の責任は誠に 重且大なりと云点可きであると思ひます。大變不十分で ありましたがてれで私の講演を終り度いと思ひます。

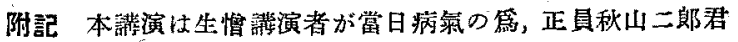

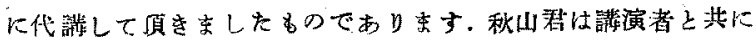

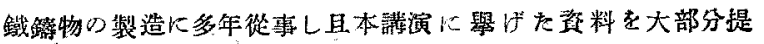
供して下さつにものであり茲に表心より厚く謝意を表します。

\section{齋 藤 豐 三*}

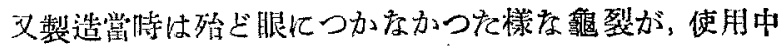

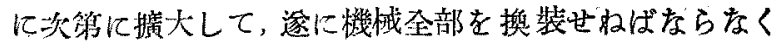

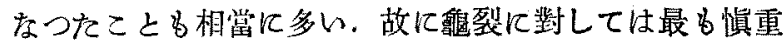
に取投は权ばならぬ。

\section{I. 龜裂發生の時期}

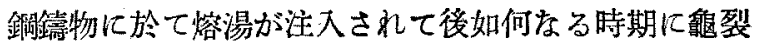
が起るかといることは，未だ明確に物つて居ない:英國

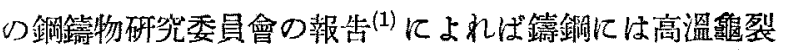
と低溫百裂との2 種があるが主として起る龜裂は高溫の

(1) J. Iron \& Steel Inst. Special Report No. 3 (1933). 